\title{
INFLUENCE OF LOCAL ASCORBIC ACID CONCENTRATION ON COLLAGENOUS TISSUE HEALING IN THE CORNEA*
}

BY

\author{
T. A. S. BOYD \\ Nuffield Laboratory of Ophthalmology, Oxford
}

IT is now accepted that the repair of collagenous tissue depends on an adequate intake of ascorbic acid (Höjer, 1924; Wolbach and Howe, 1926). Bourne (1942a) has fully reviewed the experimental work.

The relation of local ascorbic acid concentration to collagenous tissue healing, however, has not been so fully investigated. Some disagreement is apparent when the effect of the addition of ascorbic acid to connective tissue cultures is compared with that of local application of ascorbic acid to healing wounds. Table I summarizes the results recorded in the literature of the local application of ascorbic acid.

TABLE I

PREVIOUS STUDIES OF THE LOCAL APPLICATION OF ASCORBIC

ACID TO REGENERATING COLLAGEN

\begin{tabular}{|c|c|c|c|c|}
\hline $\begin{array}{c}\text { Type of } \\
\text { Experiment }\end{array}$ & Author & Date & Animal or Tissue & $\begin{array}{l}\text { Effect of Local } \\
\text { application of } \\
\text { Ascorbic Acid }\end{array}$ \\
\hline Tissue culture & $\begin{array}{l}\text { Jeney and Törö } \\
\text { Querido and } \\
\text { Gaillard }\end{array}$ & $\begin{array}{l}1936 \\
1939\end{array}$ & $\begin{array}{l}\text { Fibroblasts and fibre } \\
\text { production } \\
\text { Osteogenic cells and } \\
\text { collagen fibre produc- } \\
\text { tion }\end{array}$ & $\begin{array}{l}\text { Increased growth } \\
\text { Increased growth }\end{array}$ \\
\hline $\begin{array}{l}\text { Experimental } \\
\text { wounds to } \\
\text { normal } \\
\text { animals }\end{array}$ & 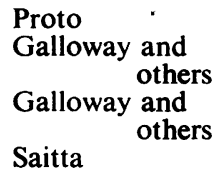 & $\begin{array}{l}1936 \\
1948 \\
1948 \\
1929\end{array}$ & $\begin{array}{l}\text { Rabbits } \\
\text { Rats } \\
\text { Guinea-pigs } \\
\text { Guinea-pigs }\end{array}$ & $\begin{array}{l}\text { No effect } \\
\text { No effect } \\
\text { No effect } \\
\text { Increased healing }\end{array}$ \\
\hline $\begin{array}{l}\text { Experimental } \\
\text { wounds to } \\
\text { scorbutic } \\
\text { animals }\end{array}$ & $\begin{array}{l}\text { Saitta } \\
\text { Galloway and } \\
\text { Persson }\end{array}$ & $\begin{array}{l}1929 \\
1948 \\
1953\end{array}$ & $\begin{array}{l}\text { Guinea-pigs } \\
\text { Guinea-pigs } \\
\text { Guinea-pigs }\end{array}$ & $\begin{array}{l}\text { Increased healing } \\
\text { Increased healing } \\
\text { Increased healing }\end{array}$ \\
\hline
\end{tabular}

Jeney and Törö (1936) added ascorbic acid to the culture medium in which fibroblasts were being grown and showed that fibres were produced more rapidly after this addition. Confirmation of these experiments was reported by Querido and Gaillard (1939), who cultured osteogenic cells from the

*Received for publication December 28, 1954. 
chick in three types of plasma; from scorbutic guinea-pigs, from scorbutic guinea-pigs but with crystalline ascorbic acid added to the culture medium, and from scorbutic guinea-pigs treated with large doses of ascorbic acid before the experiment. Hardly any collagen fibres were formed by the cells in the first plasma, but in the second and third culture media fibres were formed as rapidly as in normal plasma.

In contrast with these in vitro experiments, reports on the effect of the application of ascorbic acid to wounds in living animals are less concordant. Proto (1936) found that local application of ascorbic acid to wounds of normal rabbits did not affect healing. Galloway, Garry, and Hitchin (1948) reported that direct application of 3 per cent. sodium ascorbate did not accelerate the rate of healing of thigh wounds in normal rats. These workers again had negative results when they applied 3 per cent. sodium ascorbate to thigh wounds in guinea-pigs which were receiving $5 \mathrm{mg}$. ascorbic acid daily by mouth.

On the other hand, Saitta(1929)found that he could accelerate the healing of wounds in guinea-pigs by local application of ascorbic acid whether they were fed on a normal or a scorbutic diet. Galloway and others (1948) also applied ascorbic acid locally to wounds in scorbutic guinea-pigs and found that 3 per cent. sodium ascorbate accelerated healing. This may have been due to the local raising of the ascorbic acid level in the healing tissues, but it seems, in view of the large amount of sodium ascorbate used, that the effect may have been obtained by absorption of ascorbic acid into the circulation. Persson (1953) has obviated this criticism by applying quantities incapable of influencing the general ascorbic acid content of the tissues. The wounds he inflicted on scorbutic guinea-pigs were treated with $0.05 \mathrm{mg}$. per day and he was able to observe, after 3 to 4 days, a moderate amount of metachromatically staining ground substance and reticular fibres in the intercellular spaces which were not present in other wounds in the same animals treated with $\mathrm{H}_{2} \mathrm{O}$. Unfortunately the duration of his experiment did not allow the production of collagen fibres.

It would seem therefore from these discordant results that it is still not clear whether collagen healing depends on the concentration of ascorbic acid in its immediate vicinity and this point therefore warrants further investigation. It is possible that one might obtain an unequivocal answer to the problem if two different ascorbic acid levels could be produced in identical tissues in the same animal; this would avoid the differences which inevitably exist between animal and animal. One could then investigate healing rates in the two tissues to find whether the tissue with the higher ascorbic acid content would heal faster. Such a proposition becomes practical if one considers the corneae of the two eyes of the same animal.

The presence of a high ascorbic acid concentration in the aqueous humour, originally described by Harris (1933), has been amply confirmed in many species including guinea-pigs and man. Pirie (1946) has shown that ox 
cornea also contains a high concentration of ascorbic acid, greatest in the epithelium, and in the stroma about equal to the aqueous concentration. She also showed that the corneal endothelium of freshly excised ox eyes is permeable to ascorbic acid, and from her results suggested that the aqueous level is responsible for the corneal level.

Müller and Buschke (1934) described the lowering of the aqueous ascorbic acid concentration which occurs when the lens is removed from the eye. Although this fact has been contradicted by some workers, it has been largely confirmed (Müller, Buschke, Gurewitsch and Bruhl, 1934; Bietti and Carteni, 1934; Langham, 1949).

These findings suggested that it would be feasible to remove the lens of one eye of a series of animals and in this way produce different corneal ascorbic acid levels in the two eyes. To test this hypothesis the left lenses of ten guinea-pigs were removed (Table II). The animals were maintained on a diet containing cabbage. Thereafter repeated estimations of ascorbic acid were made of aqueous humour and a final estimation of the corneae.

TABLE II

AQUEOUS HUMOUR AND CORNEAL ASCORBIC ACID LEVELS FROM NORMAL AND APHAKIC EYES

\begin{tabular}{|c|c|c|c|c|c|}
\hline \multirow{2}{*}{ Substance } & \multicolumn{2}{|c|}{ Aphakic Eyes } & \multicolumn{2}{|c|}{ Normal Eyes } & \multirow{2}{*}{$\begin{array}{l}\text { Probability } \\
\text { of Chance } \\
\text { Occurrence }\end{array}$} \\
\hline & $\begin{array}{l}\text { Ascorbic Acid } \\
\text { (mg./100 ml.) }\end{array}$ & $\begin{array}{c}\text { No. of } \\
\text { Estimations }\end{array}$ & $\begin{array}{l}\text { Ascorbic Acid } \\
\text { (mg./100 ml.) }\end{array}$ & $\begin{array}{c}\text { No. of } \\
\text { Estimations }\end{array}$ & \\
\hline Aqueous & $11 \cdot 60( \pm 0.87)^{*}$ & 21 & $22 \cdot 16( \pm 1 \cdot 13)$ & 21 & $P<0.001$ \\
\hline Cornea & $31 \cdot 51( \pm 7 \cdot 29)$ & 9 & $51 \cdot 35( \pm 6 \cdot 59)$ & 9 & $P<0.1$ \\
\hline
\end{tabular}

${ }^{*}$ Figures in brackets $=$ standard error of the mean.

The mean ascorbic acid level in the aqueous humour of the aphakic eyes was $11.6 \pm 0.87 \mathrm{mg} . / 100 \mathrm{ml}$. (21), whereas the mean of the levels in the normal eyes was $22 \cdot 16 \pm 1 \cdot 13 \mathrm{mg} . / 100 \mathrm{ml}$. (21). The difference, $10 \cdot 56 \mathrm{mg}$./ $100 \mathrm{ml}$., is significant $(P<0.001)$. For the corneae the mean ascorbic acid level in the aphakic eyes was $31 \cdot 51 \pm 7 \cdot 29 \mathrm{mg}$./ $100 \mathrm{~g}$. (9) and in the normal eyes $51 \cdot 35 \pm 6.59 \mathrm{mg} . / 100 \mathrm{~g}$. (9). In this case the difference, $19 \cdot 84 \mathrm{mg} . / 100$ ml., is not significant, probably on account of the small number and scatter of observations $(P<0 \cdot 1)$ (Boyd, 1954). However, these results were encouraging, and it was planned to remove the lenses from one eye in a further series of guinea-pigs and then to subject the corneae to experimental injuries. It is clear that if collagen production depends on a local level of ascorbic acid the rate of healing in the cornea of the aphakic eye should be slower than that in the normal eye.

\section{Method}

The left lens of 42 adult guinea-pigs was removed and control operations were performed on the right eye. 


\section{Preparation of Animals}

Diet.-The animals were fed on a mixture of M.R.C. Diet 18 (one-third) and bran (twothirds), moistened with a little water; cabbage and water ad lib were available; $2 \mathrm{ml}$. cod liver oil were added once a week to the diet of each animal.

Pre-operation.-The animals were prepared for operation by shaving the hair from the eyelids and by vigorously cleansing the head area with C.T.A.B.

Anaesthesia.-They were anaesthetized with ether; induction was performed by covering the animal with an ether-soaked duster and placing it in a closed glass jar. When unconscious it was removed from the jar and anaesthesia maintained by an oxygenether mixture administered into a small face mask.

Operation.-The eye was opened and the eyelids retracted by sutures which were used at the end of the operation to close the eye. A superior conjunctival flap was turned down and dissected free from the limbal sclera. A small ab externo incision close to and parallel with the limbus was made at 12 o'clock with a Graefe knife and extended to 10 and 2 o'clock with scissors. A wide iridectomy of the Graefe type was performed to ensure a clear route for delivery of the lens. An attempt was made to break down the zonule by massage on the lower limbus with the tip of an iris repositor. When the lens seemed to be subluxated it was expressed by pressure at the limbus directed to the centre of the globe. Counter pressure was applied with a Critchett's spoon to the sclera at 12 o'clock just above the wound. In this way by gentle but increasing compression the lens was tumbled from below and separated from its normal adhesion to the anterior vitreous face. The conjunctival flap was then secured by tying two preplaced sutures and after instilling penicillin drops $(1,000 \mathrm{units} / \mathrm{ml}$.) the two lid retraction sutures were tied, thus closing the lids.

A control operation was then performed on the right eye. The same procedures were followed, with the exception of the removal of the lens.

As far as possible these operations were performed under aseptic conditions, using sterile towels to isolate the operation area.

Post-operation.-During the post-operative period penicillin drops were instilled twice daily for 10 days. The lid sutures often cut out spontaneously, but if not they were removed on the tenth day.

These lens extractions were subject to operative and post-operative complications, similar to, but more frequent than, those one meets in human lens extractions. Of 42 animals, twenty were considered satisfactory for use in the next part of the experiment. These animals were chosen because the inflammation had clinically subsided, the corneae were clear, soft lens matter-if any-had absorbed and the corneo-scleral wounds were firmly healed. The control operations on the right eyes were intended to cause trauma comparable to that inflicted on the left eyes. It was clear that in the post-operative phase the right eye settled a little sooner than the left eye; no doubt because trauma was less severe. Occasional minor corneal vascularization was noted in both right and left eyes.

\section{Corneal Healing Experiment}

Diet.-During the course of the corneal healing it was desirable that each animal should receive an equal amount of ascorbic acid so that the ocular levels would be comparable. Experiments on a series of control animals showed that a cabbage diet produced varying levels of aqueous ascorbic acid. Cabbage was therefore withdrawn and replaced with $20 \mathrm{mg}$. ascorbic acid in solution, given daily to each animal by pipette. A small trial showed that this intake in normal guinea-pigs maintained a mean aqueous level of $22.36 \pm 0.02 \mathrm{mg}$. $/ 100 \mathrm{ml}$. (4). After withdrawal of the cabbage many of the animals lost weight. Raw peeled apple $(50 \mathrm{mg}$. daily) was therefore added to the diet; this contained about $0.5 \mathrm{mg}$. ascorbic acid, insufficient to add significantly to the daily ration given by pipette. 
Throughout the 4 weeks of the corneal healing experiment all twenty guinea-pigs either maintained or gained weight.

Standardized Corneal Injuries.-With modifications the technique employed by Campbell, Ferguson, and Garry (1950) was used.

Heat injuries were inflicted with an electro-cautery made of a loop of 32 S.W.G. platinum wire. The cautery was heated for exactly one second by a predetermined constant current supplied through a switch operated by a synchronous motor. The corneae were anaesthetized by instilling one drop 4 per cent. cocaine into the conjunctival sac. Standardized heat injuries were made with a cautery held in a clamp attached to the moving stage of a microscope. The animal was held so that the point of the cold cautery was touching the cornea $3 \mathrm{~mm}$. from the limbus. While the animal was held steady the cautery was advanced by $1 \mathrm{~mm}$. thus exerting a constant pressure. Current was then supplied to the cautery for one second, and contact with the cornea was maintained for the subsequent second while it was cooling.

The predetermined current was sufficient to cause maximal injury to the corneal stroma, without causing perforation.

Assessment of Healing.-The method used by Boyd and Campbell (1950) was followed. One drop 2 per cent. aqueous solution of sodium fluorescein was instilled into the conjunctival sac; after one minute excess fluorescein was washed off with a stream of warm saline delivered from a plastic wash-bottle. The animal was then placed in a darkened viewing box 6" below a mercury vapour lamp fitted with a Wood's glass screen. The intensity of fluorescence of the injury was then measured by placing alongside the animal's eye a series of standard strips of filter paper impregnated with varying concentrations of sodium fluorescein.

The standard consisted of five strips, $1 \times \frac{1}{2}$ in., of Whatman No. 1 filter paper impreg-

TABLE III

RELATION OF CONCENTRATION OF SODIUM FLUORESCEIN TO INTENSITY OF FLUORESCENCE FROM STANDARD STRIPS OF FILTER PAPER

\begin{tabular}{c|c}
\hline Intensity of Fluorescence & $\begin{array}{c}\text { Concentration of Fluorescein } \\
\left(\mu \mathrm{g} . / \mathrm{cm} .^{2} \text { filter paper }\right)\end{array}$ \\
\hline 0 & Nil \\
1 & $0 \cdot 5$ \\
2 & 1 \\
3 & 2 \\
4 & 4 \\
5 & 8 \\
\hline
\end{tabular}
nated with fluorescein so that the intensity of fluorescence increased in approximately linear steps (Campbell and Boyd, 1950). Table III gives details of these standard strips.

As healing of the corneal injury progresses, the intensity of fluorescence decreases and finally ceases when epithelialization has reached a certain stage (Pflüger, 1882). The time of healing was recorded as until the fourth of four consecutive observations of "no fluorescence". the interval from injury

Assessment of Vascularization.-All the corneae were examined with a corneal microscope and a Hamblin Universal slit-lamp 9 days after injury and again after the injury had healed. Diagrams of the vascularization were made at each examination, indicating the sectors as on a clock face invaded by vessels, the density of the invasion being shown as one of three degrees. The area involved was expressed in arbitrary units up to a total of twelve.

Preparation of Tissue Extracts.-Within a week of healing the ascorbic acid concentration in the cornea, aqueous, and vitreous humours, was assessed.

The animal was killed by chloroform and ether inhalation. Before death had actually occurred the aqueous was extracted by puncturing the cornea with a very fine capillary 
tube, the tip of which had been broken to form a sharp point; this sharp point pierced the cornea with little effort and the pressure exerted was sufficient to express aqueous into the tube.

Thereafter the eye was enucleated, the vitreous expressed from an incision in the posterior sclera, and the cornea removed by a scissors incision around the limbus, care being taken to disturb the epithelium and endothelium as little as possible.

Each of the specimens of cornea, aqueous, and vitreous was directly transferred to a weighed corked tube containing a weighed amount of 5 per cent. metaphosphoric acid (about $0.2 \mathrm{~g}$. for aqueous and vitreous and $0.3 \mathrm{~g}$. for cornea). These tubes were immediately recorked and reweighed. Specimens of cornea, aqueous, and vitreous weighed about 15,60 , and $150 \mathrm{mg}$. respectively.

The specimen of aqueous was centrifuged if the presence of protein precipitate made this necessary. The vitreous was broken up with a glass rod and centrifuged. To the corneal specimen was added a small quantity of acid-washed sand and it was ground with a glass rod to fine fragments against the bottom of the tube, then centrifuged. The supernatant fluid of each was used for titration against freshly prepared 2 :6-dichloroindophenol, made up in solution so that $1 \mathrm{ml}$. was equivalent to $0.1 \mathrm{mg}$. ascorbic acid.

Microtitration of Ascorbic Acid.-The dye was contained in an Agla micro-syringe and the volume of the metaphosphoric acid extract taken was adjusted to give a titration of between 0.0075 and $0.0150 \mathrm{ml}$. dye, for between these limits the end-point was found to be sharpest. The volume of the extract which gave this titration was usually 0.02 or $0.03 \mathrm{ml}$., and this was delivered from another Agla micro-syringe.

The titration was performed on a small plastic platform coated with paraffin, which was held in a retort clamp. Adequate mixing during titration was effected by vibrating the platform with an electric buzzer clamped to the retort stand. With the quantities available it was possible to obtain six or more titrations with aqueous and vitreous, but only three with the corneal specimen.

\section{Results}

The following results, which are summarized in Table IV, are derived from observations made during the healing of the experimental heat injuries inflicted on the corneae of twenty guinea-pigs (eighteen non-pregnant females and two males). All twenty aphakic eyes were used, but one of the twenty eyes subjected to control operation is not included in the results as the injury had not healed even after 24 days, on account of a vesicular condition which developed in the corneal epithelium.

TABLE IV

COMPARISON OF HEALING IN APHAKIC AND CONTROL CORNEAE

\begin{tabular}{|c|c|c|c|c|c|}
\hline \multirow{2}{*}{$\begin{array}{l}\text { Assessment of } \\
\text { Healing Process }\end{array}$} & \multicolumn{2}{|c|}{ Aphakic Eyes } & \multicolumn{2}{|c|}{ Control Eyes } & \multirow{2}{*}{$\begin{array}{l}\text { Probability } \\
\text { of Chance } \\
\text { Occurrence }\end{array}$} \\
\hline & Mean & $\begin{array}{l}\text { No. of } \\
\text { Eyes }\end{array}$ & Mean & $\begin{array}{l}\text { No. of } \\
\text { Eyes }\end{array}$ & \\
\hline \multirow{2}{*}{$\begin{array}{l}\text { Time (days) } \\
\text { Relapses } \\
\text { Relapse Frequency } \\
\text { No. of Vascularized } \\
\text { Sectors }\end{array}$} & $\begin{aligned} 17 \cdot 3 & ( \pm 0 \cdot 84)^{*} \\
6 \cdot 1 & ( \pm 1 \cdot 94) \\
3 \cdot 9 & ( \pm 0 \cdot 39)\end{aligned}$ & $\begin{array}{l}20 \\
19 \\
19\end{array}$ & $\begin{aligned} 10 \cdot 8 & ( \pm 2 \cdot 2) \\
2 \cdot 8 & ( \pm 0 \cdot 53) \\
2 \cdot 7 & ( \pm 0 \cdot 44)\end{aligned}$ & $\begin{array}{l}19 \\
19 \\
19\end{array}$ & $\begin{array}{l}P<0.001 \\
P<0.001 \\
P<0.05\end{array}$ \\
\hline & $11 \cdot 3( \pm 2 \cdot 15)$ & 20 & $6 \cdot 7( \pm 1 \cdot 56)$ & 19 & $P<0.1$ \\
\hline
\end{tabular}

- Figures in brackets = standard error of the mean. 
Healing Time--Analysis of the time taken for the corneal injuries to epithelialize showed that the average for the twenty aphakic eyes was $17 \cdot 3$ $\pm 0 \cdot 84$ days (20), whereas for the nineteen control eyes on which a control operation had been performed it was $10 \cdot 8 \pm 2 \cdot 2$ days (19). The difference, 6.5 days, is significant $(P<0.001)$.

The mean intensity of fluorescence at each observation was plotted during the healing of injuries in the control and aphakic eyes (Figure). Until the seventh day of observation there was little difference in the mean fluorescence from the two sets of corneae. However, after the eighth day, repeated

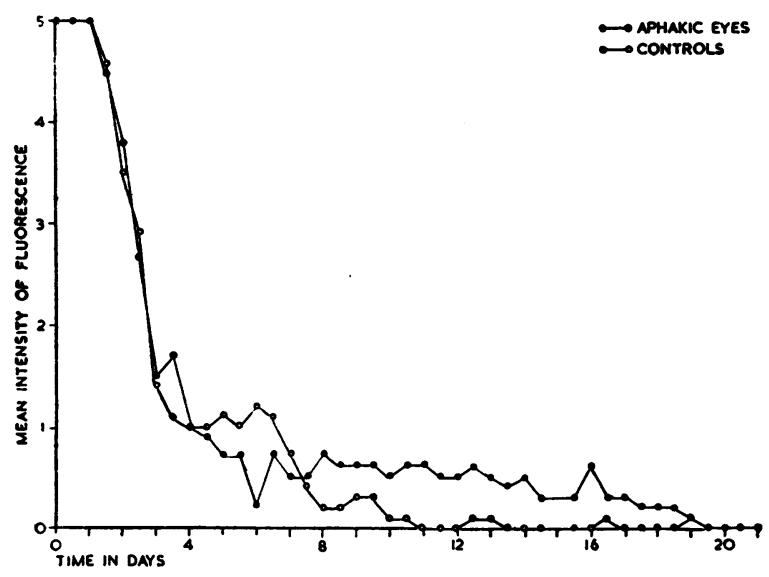

FiguRE.-Mean intensity of fluorescence of heat injuries to corneae in aphakic and control eyes plotted twice daily during healing. Ordinate corresponds to strip intensities described in the text. increases in fluorescence which occurred in each eye. The mean number of
relapses for the aphakic eyes was $6 \cdot 1$, whereas for the control eyes it was $2 \cdot 8$. The difference, $3 \cdot 3$, is significant $(P<0 \cdot 001)$.

Frequency of Relapses. - It is clear that, as the aphakic eye injuries took longer to heal, there was greater opportunity for relapses to occur. The frequency of relapses in the aphakic and control eyes was therefore compared over equal periods during the course of healing, the period in each case being the time taken.by the eye which healed first. Estimating the relapse rate in this way it was found that the mean frequency in the aphakic eyes was 3.9 , whereas in the control eyes it was $2 \cdot 7$. The difference, $1 \cdot 2$, was significant $(P<0.05)$.

Corneal Vascularization.-Analysis of the observations of corneal vascularization, both on the ninth day after injury and after healing was complete, indicated that the mean blood vessel invasion of the aphakic corneae was slightly more than that of the control corneae. However, statistical analysis 
showed that this difference was not significant, either for the area vascularized or for the density of vascularization.

Biochemical Results. - Table V shows the mean concentration of ascorbic acid in the cornea, aqueous, and vitreous after healing had occurred in the aphakic and control eyes. In each case the mean level was lower in the aphakic eye than in the control eye. For the corneae the difference between the means was $13.22 \mathrm{mg}$. $/ 100 \mathrm{ml}$. and this difference was significant $(P<0.01)$. For the aqueous humour the difference was $2.75 \mathrm{mg} . / 100 \mathrm{ml}$., a significant difference $(P<0 \cdot 02)$. For the vitreous humour the difference was $4.59 \mathrm{mg}$./ $100 \mathrm{ml}$., not significant.

TABLE V

LEVELS OF OCULAR ASCORBIC ACID AFTER HEALING

\begin{tabular}{|c|c|c|c|c|c|}
\hline \multirow{2}{*}{ Substance } & \multicolumn{2}{|c|}{ Aphakic Eyes } & \multicolumn{2}{|c|}{ Control Eyes } & \multirow{2}{*}{$\begin{array}{l}\text { Probability } \\
\text { of Chance } \\
\text { Occurrence }\end{array}$} \\
\hline & $\begin{array}{l}\text { Ascorbic Acid } \\
\text { (mg./100 g.) }\end{array}$ & $\begin{array}{l}\text { No. of } \\
\text { Eyes }\end{array}$ & $\begin{array}{l}\text { Ascorbic Acid } \\
\text { (mg./100 g.) }\end{array}$ & $\begin{array}{l}\text { No. of } \\
\text { Eyes }\end{array}$ & \\
\hline $\begin{array}{l}\text { Cornea } \\
\text { Aqueous } \\
\text { Vitreous }\end{array}$ & $\begin{aligned} & 32 \cdot 09( \pm 5 \cdot 62)^{*} \\
& 9 \cdot 70( \pm 0 \cdot 62) \\
& 12 \cdot 10( \pm 0 \cdot 94)\end{aligned}$ & $\begin{array}{l}18 \\
17 \\
17\end{array}$ & $\begin{array}{l}47 \cdot 29( \pm 14.03) \\
12.45( \pm 0.79) \\
16.69( \pm 1.03)\end{array}$ & $\begin{array}{l}18 \\
17 \\
16\end{array}$ & $\begin{array}{l}P<0.01 \\
P<0.02 \\
P<0.1\end{array}$ \\
\hline
\end{tabular}

*Figures in brackets = standard erroriof the mean.

\section{Discussion}

Relation of Local Ascorbic Acid Level to Collagen Healing.-Bourne (1942) suggested that, so long as the bulk of tissue to be repaired does not make demands in excess of the available supply (whether it be oral intake as in guinea-pigs and man, or synthesis as in all other animals), there should be no advantage in giving additional ascorbic acid either locally or systemically.

If this hypothesis be true it would explain the healing of wounds in scorbutic animals after local treatment with ascorbic acid (Galloway and others, 1948; Saitta, 1929; Persson, 1953). It would also explain why normal animals which synthesize their own ascorbic acid and guinea-pigs receiving an adequate dietary intake should fail to show accelerated healing when the vitamin was applied locally (Proto, 1936; Galloway and others, 1948). However, this does not readily explain the findings of Saitta (1929) who wounded normal guinea-pigs and was able to hasten healing by local application. The hypothesis can only explain these findings if the wounds were relatively large in relation to the available ascorbic acid.

There is no doubt that Bourne's hypothesis cannot explain why the aphakic corneal wounds reported here should take a 40 per cent. longer time to heal than the control corneae. The wounds were relatively small $(1 \mathrm{~mm}$. in diameter and not quite the thickness of the cornea), and they were certainly very small in relation to the available ascorbic acid. Not only were the guinea-pigs receiving $20 \mathrm{mg}$./day (about ten times the normal requirement), but even the aphakic corneal level of ascorbic acid was several times the 
level in most connective tissue. It seems reasonable to suggest that the rate of healing of collagen depends on the local concentration of ascorbic acid, even though it exceed the level required for normal metabolism.

Relation of Ascorbic Acid Intake to Optimum Collagen Healing.The conclusion arrived at above leads to the question of an optimum intake of ascorbic acid which will enable collagen to heal at its maximum rate. Animals which synthesize their own ascorbic acid would be expected to maintain a blood level adequate for all purposes. Nevertheless Hanke (1935) found that, if rabbits were kept on a scorbutic diet, though they regenerated bone completely, the rate was much retarded.

Giangrasso $(1938,1939 a, b)$ found that fractures in rabbits healed twice as fast when their diet was augmented with extra ascorbic acid. In contrast, Bourne $(1942 b, c)$ found that extra vitamin given to rats did not accelerate the rate of healing of $1 \mathrm{~mm}$. holes in their bones. Both these results are fully in concordance with his theory. He concedes that extra vitamin may well hasten the rate of healing of a gross injury such as a fracture in an animal which manufactures its own ascorbic acid. Such an injury may make demands greater than can be supplied by the animal's normal mechanism of production.

However, Boyd and Campbell (1950) found that the healing of small collagen lesions in humans receiving adequate diet could be accelerated by giving extra ascorbic acid. They found that administration of $1.5 \mathrm{~g}$. ascorbic acid daily to a random selection of patients suffering from small corneal ulcers significantly accelerated their rate of healing as compared with a group who received control tablets containing no ascorbic acid. This finding strongly suggests, in contradiction to Bourne's hypothesis, that the optimum intake for collagen healing is greatly in excess of the level required for normal metabolism.

The present findings support this suggestion. If a difference in healing rates can be demonstrated when the ascorbic acid level is about ten times most tissue levels, it is reasonable to conclude that the optimum intake for maximum collagen healing is higher than previously suspected.

Ascorbic Acid and Epithelial Healing.-The course of healing in our experimental injuries was followed by the use of fluorescein. This test depends on the degree to which epithelium covers the underlying collagen stroma. The stroma becomes deeply stained when the overlying epithelium is absent. Campbell, Ferguson, and Garry (1950), experimenting with guinea-pigs, and Boyd and Campbell (1950), observing humans, used this test to show that epithelialization in superficial corneal lesions is unaffected by ascorbic acid, but that in deep lesions ascorbic acid causes a significant acceleration in healing. This was ascribed to the effect of ascorbic acid on the collagen underlying the regenerating epithelium.

In the present experiment the fluorescein test again showed that the action of ascorbic acid on corneal collagen affected the regeneration of epithelium. 
The relapses which occurred during healing suggest that the corneal epithelium was attempting to cover the lesion, but that the underlying stroma was unable to support it. This lack of support seemed more marked in the aphakic corneae; not only did they break down more often during healing, but the frequency of break-down per unit time was greater. This is in keeping with the hypothesis of Hartwell (1929) who studied skin epithelialization. He stated that healthy epithelium depends upon a healthy substratum of collagenous tissue. This is illustrated by Smith and McConkey (1933) who found that scarified duodenal mucosa failed to heal in scorbutic guinea-pigs, but healed promptly in normal controls.

Ascorbic Acid and Corneal Vascularization.-Campbell and Ferguson (1950) showed that corneal vascularization occurred more readily in scorbutic than in normal guinea-pigs when their corneae were subjected to experimental heat injuries. The findings reported in this paper tend to confirm this work. Expressed in arbitrary units, more vascularization occurred in the aphakic than in the control corneae, but the difference between them was not statistically significant; there was a probability of chance occurrence of between $1: 10$ and $1: 20$.

Ascorbic Acid Concentration in Aqueous Humour before and after Injury.An unexpected result of ophthalmic interest has arisen from the observations reported here. The mean ascorbic acid concentration in the aqueous humour of the normal guinea-pigs given $20 \mathrm{mg}$. ascorbic acid per day was $22 \cdot 36 \pm$ $0.02 \mathrm{mg} . / 100 \mathrm{ml}$. (4). However, after injuring the corneae of the aphakic eyes and allowing these injuries to heal (healing being judged by the arbitrary conditions of the fluorescein test), the mean concentration of ascorbic acid in the aqueous humour was $12.45 \pm 0.79 \mathrm{mg} . / 100 \mathrm{ml}$. (17), although these animals were also being given $20 \mathrm{mg}$. ascorbic acid daily. The difference between these two means is not statistically significant $(P<0 \cdot 1)$, probably because only four observations were made on normal guinea-pigs. Nevertheless, the possibility of a difference is interesting.

It is known that the concentration of the constituents of the aqueous humour approximates to that of the blood plasma when the eye is inflamed (Duke-Elder and Goldsmith, 1951). It may be that residual inflammation resulting from the injury caused this lowering of the ascorbic acid in the aqueous humour. If this be so, then the fact that the ascorbic acid was lower still in the injured aphakic eyes $(9.70 \pm 0.62 \mathrm{mg}$. $/ 100 \mathrm{ml}$. (17)) might simply mean that the aphakic eyes were more inflamed than the injured eyes which still contained their lenses.

Kinsey (1950) found that uninflamed aphakic eyes of rabbits had normal ascorbic acid concentration, but that the concentration was lowered in inflamed aphakic eyes. It is impossible to judge whether the many reports of lowered ascorbic acid in the aqueous humour in aphakia can all be ascribed to inflammation in the eye. Kinsey's observation on uninflamed aphakic rabbit eyes has now been confirmed by Purcell, Lerner, and Kinsey (1954) on 
uninflamed aphakic human eyes. They extracted the aqueous humour from two human eyes 4 months after intracapsular extraction of the lens and found the ascorbic acid concentration normal, about twenty times that of the plasma level.

\section{Summary}

(1) The left lenses of twenty guinea-pigs were removed and control operations were performed on the right eyes.

(2) While the animals were receiving a known high intake of ascorbic acid, standardized heat injuries were inflicted on the corneae.

(3) The aphakic corneae took 40 per cent. longer to heal than the controls.

(4) When healing was complete, by the arbitrary standards of the experiment, the ascorbic acid content of corneae, aqueous, and vitreous humours was assessed. The mean ascorbic levels of aphakic corneae and aqueous humour were significantly lower than those of the controls. The aphakic vitreous humour level was lower, but not significantly so.

(5) These findings suggest that local ascorbic acid concentration may be responsible for the rate at which collagen heals.

I wish to express my thanks to Mrs. A. Pirie and Mrs. R. van Heyningen for helpful advice and criticism, to Miss Blackwell, Miss Connell, and Mr. Redding for much technical assistance, to Miss Neville and Miss Müller for help in translating foreign papers, and to Miss Hutchinson for correcting the manuscript.

\section{REFERENCES}

Bartlett, M. K., Jones, C. M., and Ryan, A. E. (1942). New Engl. J. Med., $226,469$.

BietTi, G., and CARTENI, A. (1934), Boll. Soc. ital. Biol. sper., 9, 283.

BOURNE, G. H. (1942a). Lancet, 2, 661.

(1942b). Quart. J. exp. Physiol., 31, 319.

(1942c). J. Physiol. (Lond.), 101, 327.

BoyD, T. A. S. (1954). Unpublished results. , and CAMPBelL, F. W. (1950). Brit. med. J., 2, 1145

CAMpbell, F. W., and Boyd, T. A. S. (1950). British Journal of Ophthalmology, 34, 545. , and FERGUSON, I. D. (1950). Ibid., 34, 329.

-

Duke-Elder, S., and GoldSMith, A. J. B. (1951). "Recent Advances in Ophthalmology", 4th ed., p. 9. Churchill, London.

Galloway, N. M., Garry, R. C., and Hitchin, A. D. (1948). Brit. J. Nutrit., 2, 228.

Giangrasso, G. (1938). Fisiol. e Med., 9, 255.

(1939a). Arch. ed atti Soc. ital. Chir., 45, 822

(1939b). Boll. Soc. ital. Biol. sper., 14, 522.

Hanke, H. (1935), Disch. Z. Chir., 245, 530.

HARRIS, L. J. (1933). Nature (Lond.), 132, 27.

HARTWEll, S. W. (1929). Arch. Surg. (Chicago), 19, 835.

HöJER, J. A. (1924). "Studies in Scurvy". Acta paediatr. (Uppsala), 3, Suppl. 1, p. 8.

JENEY, A. vON, and Törö, E. (1936). Virchows Arch. path. Anat., 298, 87.

KINSEY, V. E. (1950). Amer. J. Ophthal., 33, 257.

LANGHAM, M. (1949). " Dynamic Studies on the Lens." Thesis, University of London.

Müller, H. K., and BuschKe, W. (1934). Arch. Augenheilk., 108, 368.

MUl, Gurewitsch, A., and BrüHL, F. (1934). Klin. Wschr., 1, 20.

Persson, B. H. (1953). Acta Soc. Med. upsalien., Suppl. 2.

PFlüger, (1882). Klin. Mbl. Augenheilk., 20, 69.

PIRIE, A. (1946). Biochem. J., 40, 96.

Proto, M. (1936). Ann. ital. Chir., 15, 31.

Purcell, E. F., Lerner, L. H., and KInSey, V. E. (1954). Arch. Ophthal. (Chicago), 51, 1.

Querido, A., and GaIllard, P. J. (1939). Acta brev. neerl. Physiol., 9, 70.

SaITTA, S. (1929). Scr. biol. Castaldi, 4, 301.

SMITH, D. T., and McConkey, M. (1933). Arch. intern. Med., 51, 413.

Wolbach, S. B., and Howe, P. R. (1926). Arch. Path. (Chicago), 1, 1. 